\title{
Effect of Telenursing and Diabetes Self-Management Education Towards Fasting Blood Glucose in type 2 diabetes mellitus
}

\author{
Iin Patimah ${ }^{1}$, Andri Nugraha ${ }^{2}$, Iwan Wahyudi ${ }^{3}$, Susan Susyanti $^{4}$, Tri Listyorini ${ }^{5}$ \\ \{iinpatimah84@gmail.com ${ }^{1}$ \} \\ Department of Medical Surgical Nursing, STIKes Karsa Husada Garut ${ }^{12}$, Department of \\ Community Health Nursing, STIKes Karsa Husada Garut ${ }^{34}$, Department of Informatics Egineering, \\ Universitas Muria Kudus 5
}

\begin{abstract}
Diabetes mellitus causes complication, the decreasing quality of life, and death. One of the efforts to help people with education, but rarely followed up. That is why telenursing method needed. Telenursing is an easy, efficient, without time and dinstance barriers and it is cheaper than traditional method. It is to find out the influence of telenursing (Telephone Follow-Up) and diabetes self management education for 12 weeks towards fasting blood glucose level. The research method used quasi experiment with control group pre and posttest design; total sampling was 32 people divided into control group and intervention group, parametric measurement of data analysis used $t$ test. The result from the measurement of intervention group, it is obtained that fasting blood glucose (P value 0,00 ), and analysis result on control group obtained fasting blood glucose ( $\mathrm{P}$ value 0,00 ). There is a significant influence between telenursing (follow up via phone) with fasting blood glucose.
\end{abstract}

Keywords: diabetes mellitus tipe II, education, telenursing, telephone, follow-up.

\section{Introduction}

Diabetes Mellitus (DM) is one of the chronic disease with the incident number increases each year. WHO recorded that 442 million people suffered from DM in 2014 [1]. In 2013, Indonesia recorded that 1.5 million people suffered from DM and it was predicted to reach 21.3 million in 2030 [2]. The most common type of diabetes mellitus in the world is type $2 \mathrm{DM}$. type $2 \mathrm{DM}$ is characterized by increase glucose level caused decrease of the insulin hormone performance [3] [4]. Some risk factors that can be prevented include obesity, diet and activity [1]. Poor treatment DM causes complication, the decreasing quality of life, and death. Complication DM include: myocardial infarction, ischaemic heart disease, stroke, heart failure, amputation that leads to hypertrophic scar on post-operative wounds in certain patients [5]-[7] and psychological effect can lead stres, depression and anxiety. Anxiety disorder can exacerbate the disorder [8].

Some efforts that can be performed to decrease the risks of type $2 \mathrm{DM}$ are by maintaining blood glucose levels in normal range, and avoiding complications, such as: diet, increased physical activity, blood glucose monitoring, drug therapy (if required) and education [3], [9].

ICCSET 2018, October 25-26, Kudus, Indonesia

Copyright () 2018 EAI

DOI 10.4108/eai.24-10-2018.2280594 
Education the treatment of type $2 \mathrm{DM}$ is an important part of the patients. The education in question is by providing patients with some information and skills of the Diabetes Self-Management Education [1]. The overall purpose of the education program is to support decision making, self-care behavior, problem solving, and cooperate with health teams to actively improve clinical outcomes, health status, and quality of life [10], [11]. Education is an important part of chronic disease management, but rarely followed up.

Education on DM should be undertaken by professionals. One of which is a nurse who should be able to be actively involved in the prevention and early detection of diabetes and its complications through the provision of health care, community education, health system management, patients treatment to improve their quality of life [12].

Follow-up is one part of the nursing care process. Using the Telenursing (Telephone Follow-Up) method, patients require an ongoing monitoring of their ability to cope with illness and learn how to change their lifestyle easily and effectively despite the limited human resource situation, time, and costs that compared to traditional methods. By using the phone, the nurse can understand the patient's needs and help them meet their demands. This method can reduce patients' stress, anxiety, and depression, increase their self-esteem, and transfer patient treatment from clinics and hospitals to patients' homes [13], [14].

Telenursing is one of the methods considered by the American Nursing Association focusing on the delivery, management, coordination and service of patient treatment using telecommunications technology used in the field of nursing [15], [16]. Telenursing enables patient monitoring, health education, data collection, nursing interventions, pain management and family support through technology without time and distance constraints [17]. Telephone communications technology is the most widely available in Indonesia with $351,860,784$ people in total user, and it can reach across the vast Indonesian territory [18] with limited healthcare resources that is not in accordance with population ratios in Indonesia [19], so telenursing can be applications become more effective for this kind of situation.

\section{Research Method}

This research used quasi experiment with control group pre and posttest design. The participants of the study were 32 patients undergoing therapy treatment of type 2 DM in Regional Public Hospital of dr. Slamet of Garut, Indonesia. The participants were divided into 2 groups, they are control and intervention group. Control group is a group of patients who are given counseling of Diabetes Self-Management Education, and intervention groups is a group which received counseling of Diabetes Self-Management Education and follow up via telephone for 3 months. The group consists of 16 members each others group.

Diabetes Self-Management Education is a program that provides patients with some information and skills in the management of DM disease. Basic information that should be obtained by the patient include: Simple pathophysiology of DM (Definition, normal glucose level, therapeutic effect, food effects and stress), treatment therapy (insulin administration, dietary basics, blood glucose monitoring), prevention of complications, health service system, resource, preventive treatment (foot treatment, general hygiene, risk factor management) [20]. 
Education was given to the control group and intervention group in 1 meeting / week for 30 minutes within 4 weeks. After the education session was completed for the intervention group, the routine follow-up by telephone (telenursing) is done for 12 weeks where the first 4 weeks is $2 \mathrm{x} /$ week and the next 8 weeks $1 \mathrm{x} /$ week and the fasting blood glucose measurement was conducted before or after the cycle activities. Data analysis on this research used parametric with t test to see how significant the influence of telenursing (Telephone Follow-Up) and diabetes self management education towards fasting blood glucose.

\section{Result}

Table 1 shows that the intervention group's blood glucose level obtained on average of measurement I $199.06 \mathrm{mg} / \mathrm{dl}$ and the mean value of measurement II $175.25 \mathrm{mg} / \mathrm{dl}$. The minimum value on measurement $\mathrm{I}$ is $134 \mathrm{mg} / \mathrm{dl}$ and maximum value is $276 \mathrm{mg} / \mathrm{dl}$, while at measurement II minimum value is $109 \mathrm{mg} / \mathrm{dl}$ and maximum value is $263 \mathrm{mg} / \mathrm{dl}$.

Table 1. Blood Glucose Level Distribution in Intervention group Measurement I and Measurement II at RSUD dr Slamet Garut Year 2017

\begin{tabular}{lcccc}
\hline \multicolumn{1}{c}{ Variable } & Mean & SD & Min-Maks & 95\% CI \\
\hline Blood Glucose Level & & & & \\
Measurement I & 199,06 & 16,15 & $134-276$ & $169,14-228,99$ \\
Measurement II & 175,25 & 15,97 & $109-263$ & $145,43-205,07$ \\
\hline
\end{tabular}

Table 2 shows that the control group's blood glucose level obtained average measurement I $208.13 \mathrm{mg} / \mathrm{dl}$ and mean value of measurement II is $212 \mathrm{mg} / \mathrm{dl}$. Meanwhile, measurement $\mathrm{I}$ is at least $137 \mathrm{mg} / \mathrm{dl}$ and maximal value is $318 \mathrm{mg} / \mathrm{dl}$ and measurements of II values is at least $106 \mathrm{mg} / \mathrm{dl}$ and a maximum value is $346 \mathrm{mg} / \mathrm{dl}$

Table 2. Blood Glucose Level Distribution in Control group Measurement I and Measurement II at RSUD dr Slamet Garut Year 2017

\begin{tabular}{lcccc}
\hline \multicolumn{1}{c}{ Variable } & Mean & SD & Min-Max & 95\% CI \\
\hline Blood Glucose Level & & & & \\
Measurement I & 208,13 & 11,11 & $137-318$ & $175,56-240,69$ \\
Measurement II & 212 & 17,32 & $106-346$ & $175,35-230,77$ \\
\hline
\end{tabular}

Table 3 shows that the average of blood glucose level of the intervention groups obtained on the first measurement was $199 \mathrm{mg} / \mathrm{dl}$ with the standard deviation of 16.15 . On the second measurement, the average score obtained was $175.22 \mathrm{mg} / \mathrm{dl}$ with standard deviation 15,15 . Result of statistical test obtained value of $P$ value 0,00 . Hence, it can be concluded that there is significant difference between first and second measurement of intervention groups' blood glucose level. 
Table 3. Blood glucose Level Average Distribution in the intervention group Measurement I and Measurement II at RSUD dr Slamet Garut Year 2017.

\begin{tabular}{lccccc}
\hline Variable & Mean & SD & SE & P value & N \\
\hline Blood Glucose Level & & & & & \\
Measurement I & 199 & 16,15 & 4,03 & 0,00 & 16 \\
Measurement II & 175,25 & 15,15 & 3,99 & & \\
\hline
\end{tabular}

Table 4 shows that blood glucose level on control group at the first measurement is $208.13 \mathrm{mg} / \mathrm{dl}$ with the standard deviation of 11.11. In the second measurement, the average obtained is $212 \mathrm{mg} / \mathrm{dl}$ with a standard deviation of 17.32. Result of statistical test obtained $\mathrm{P}$ value 0,00 . Hence, it can be concluded that there is significant influence between telenursing (follow up via phone) with fasting blood glucose.

Table 4. Blood glucose Level Average Distribution in the control group Measurement I and Measurement II at RSUD dr Slamet Garut Year 2017

\begin{tabular}{lccccc}
\hline Variable & Mean & SD & SE & P value & N \\
\hline Blood Glucose Level & & & & & \\
Measurement I & 208,13 & 11,11 & 15,27 & 0,00 & 16 \\
Measurement II & 212 & 17,32 & 19,33 & & \\
\hline
\end{tabular}

\section{Discussion}

The results showed that the blood glucose level's (fasting blood glucose level) mean was $199 \mathrm{mg} / \mathrm{dl}$ in the group treatment at measurement I, while the mean score in the measurement II was $175,25 \mathrm{mg} / \mathrm{dl}$. The results showed that there was a difference of blood glucose levels before and after the treatment $(\mathrm{p}=0.000)$. Based on these results, blood glucose level in the treatment group potentially tended to decrease within ideal limits after given diabetes management education program. But, it is different from the control group that showed no change in blood glucose level to normal. From the data in Table 5.4, the mean of measurement I is $208,13 \mathrm{mg} / \mathrm{dl}$, and that of measurement II is 212 mg / dl. High blood glucose level can lead to the declining of body function that affects other organ functions such as: heart, nerves, and kidney. Therefore, blood glucose level becomes the main benchmark of a success therapy for patients with type $2 \mathrm{DM}$. Normal blood glucose level is <100 mg / dl, for fasting blood glucose and <140 mg / dl for fasting blood glucose [3].

The implementation of DM disease education management can be done with several methods. One of which is a traditional method through which a patient is given direct referral to a certain treatment center or home visits by health workers [12]. This method has flaws. The treatment center or hospital requires human resources, time, and high costs [13]. To overcome these problems, it is required an easy and efficient method which can 
save time and cost. Telenursing (Telephone Follow-Up) can be considered as one of the aforesaid method[15]. In addition to education, follow-up by telephone is established by creating links to continuous dynamic treatment, followed by improving the quality of life of patients, reducing complications, increasing patient satisfaction, and improving health and service quality [14], [16].

Educational program on the treatment management in DM patients is an important part of the DM patients treatment, especially patients with type 2 DM. Combined with Telenursing (Telephone Follow-Up), this program can be more effective and efficient. The overall objective of the education and telenursing program (Telephone Follow-Up) is to support decision-making information, self-care behavior, and problem solving, cooperate with health workers actively, and improve clinical outcomes, health status, and quality of life of patients [17] with time saving, fewer health resources and more affordable costs [14].

\section{Conclusion}

There is a significant influence between telenursing (follow up via phone) with fasting blood glucose. The telenursing (follow up via phone) can give a positive effect on blood glucose level to remain within the nomal range. The program also affects the process of dynamic behavior change based on awareness of in the type 2 DM patients to seek a healthy and quality life.

\section{References}

[1] World Health Organization, Global Report on Diabetes. Geneva 27: WHO Press, World Health Organization, 2016.

[2] Badan Penelitian dan Pengembangan Kesehatan, Riset Kesehatan Dasar (RISKESDAS). Jakarta, 2013.

[3] A. D. Association, "2. Classification and diagnosis of diabetes," Diabetes Care, vol. 39, no. January, pp. S13-S22, 2016.

[4] Dosen Keperawatan Medikal Bedah Indonesia, Rencana asuhan keperawatan medikal bedah: Diagnosa NANDA-I 2015-2017, intervensi NIC, Hasil NOC, 1st ed., no. May. Jakarta: Penerbit Buku Kedokteran EC, 2017.

[5] E. Hollander, L. Haenens, and W. J. Johannes, "Children ' s media use in Indonesia," no. March 2013, pp. 37-41.

[6] A. Nugraha, R. Chaidir, U. Rahayu, and S. Rinjani, "Factors Influencing The Occurrence Of Hypertrophic Scars Among Postoperative Patients In Garut, Indonesia," Belitung Nurs. J., vol. 3, no. 1, pp. 23-31, 2017.

[7] A. Nugraha, Nursiswati, and U. Rahayu, "faktor - faktor risiko penyakit jantung koroner pada pasien wanita di poliklinik jantung rumah sakit dr. Slamet kabupaten garut," J. Kesehat. Holist., vol. 2, no. 2, pp. 1-12, 2018.

[8] I. Patimah, Suryani, and A. Nuraeni, "Pengaruh Relaksasi Dzikir terhadap Tingkat Kecemasan Pasien Gagal Ginjal Kronis yang Menjalani Hemodialisa,” J. Keperawatan Padjadjaran, vol. 3, no. April 2015, pp. 18-24, 2015. 
[9] A. Nugraha, E. Kusnadi, and S. Subagja, "Kadar Gula Darah Sebelum dan Sesudah Melaksanakan Senam Diabetes pada Pasien Diabetes Melitus Tipe II,” J. Ilm. Kesehat., vol. IX, no. 2, pp. 1-8, 2016.

[10] Polik and rioti Maria, "The role of education in diabetes mellitus type 2 management," Heal. Sci. J., vol. 4, no. 4.

[11] M. Saffari, G. Ghanizadeh, and H. G. Koenig, "Health education via mobile text messaging for glycemic control in adults with type 2 diabetes: A systematic review and meta-analysis," Prim. Care Diabetes, vol. 8, no. 4, pp. 275-285, Dec. 2014.

[12] S. D. Burke, D. Sherr, and R. D. Lipman, "Partnering with diabetes educators to improve patient outcomes," Diabetes, Metab. Syndr. Obes. Targets Ther., vol. 7, no. 4, pp. 45-53, 2014.

[13] S. Boroumand and M. Moeini, "The effect of a text message and telephone follow-up program on cardiac self-efficacy of patients with coronary artery disease: A randomized controlled trial,” Iran. J. Nurs. Midwifery Res., vol. 21, no. 2, p. 171, 2016.

[14] V. D. Souza-Junior, I. A. C. Mendes, A. Mazzo, and S. Godoy, "Application of telenursing in nursing practice: An integrative literature review," Appl. Nurs. Res., vol. 29, pp. 254-260, 2016.

[15] K. Shea and B. Chamoff, "NIH Public Access," Worldviews Evid Based Nurs, vol. 9, no. 2, pp. 109-116, 2012.

[16] W. Glinkowski, K. Pawłowska, and L. Kozłowska, "Telehealth and Telenursing Perception and Knowledge Among University Students of Nursing in Poland," Telemed. e-Health, vol. 19, no. 7, pp. 523-529, 2013.

[17] S. J. Fard, F. Ghodsbin, M. J. Kaviani, I. Jahanbin, and Z. Bagheri, “The Effect of Follow up (Telenursing) on Liver Enzymes in Patients with Nonalcoholic Fatty Liver Disease: A Randomized Controlled Clinical Trial.," Int. J. community based Nurs. midwifery, vol. 4, no. 3, pp. 239-46, 2017.

[18] badan P. Statistik, "Jumlah Pelanggan Telepon Menurut Jenis Penyelenggaraan Jaringan 2010-2015,” 2015, Jakarta, p. 1, 20-Dec-2015.

[19] Kementrian Kesehatan Republik Indonesia, "Situasi Tenaga Keperawatan Indonesia 2017," Jakarta, 2017.

[20] M. A. Powers et al., "Diabetes self-management education and support in type 2 diabetes: A joint position statement of the American Diabetes Association, the American Association of Diabetes Educators, and the Academy of Nutrition and Dietetics," Diabetes Care, vol. 38, no. 7, pp. 1372-1382, 2015. 